\title{
Determination of blood indices of albino rats treated with aluminum chloride and investigation of antioxidant effects of vitamin $E$ and $C$
}

\author{
Ismael IS Abdel Aziz ${ }^{1}$ \& Baker M Zabut $*^{2}$ \\ 1 Biology Department, Faculty of Science, IUG, Gaza, Palestine \\ 2 Biochemistry/Chemistry Department, Faculty of Science, IUG, Gaza, Palestine
}

\begin{abstract}
The current study aims to investigate hematological and biochemical blood indices of albino rats administrated aluminum chloride $\left(\mathrm{AlCl}_{3}\right)$ for eight weeks, and to study the therapeutic effects of vitamin $\mathrm{E}$ and $\mathrm{C} . \mathrm{AlCl}_{3}$ decreased the total red blood cell count (by 18\%), hemoglobin (7\%) and hematocrit (20\%), and increased white blood cell count (67\%), lymphocytes (29\%), mean corpuscular volume (14\%), mean corpuscular hemaglobin $(6 \%)$ and platelets $(33 \%)$. Administration of vitamin $\mathrm{E}$ with or without vitamin $\mathrm{C}$ failed to restore levels of red blood cell counts, hematocrit, mean corpuscular volume, mean corpuscular hemaglobin or platelets, but vitamin $\mathrm{E}$ on its own restored levels of white blood cells, hemaglobin and lymphocytes.

$\mathrm{AlCl}_{3}$ decreased serum glucose levels by $30 \%$, and increased triglyceride (28\%) and cholesterol (20\%) levels; neither vitamin treatments restored the levels of these components. $\mathrm{AlCl}_{3}$ increased levels of urea (12\%), uric acid (77\%) and creatinine (25\%) compared to the controls, and vitamin $\mathrm{E}$ separately or together with vitamin $\mathrm{C}$ restored the levels of these nitrogen compounds.

The activities of alanine aminotransferase, alkaline phosphatase, and aspartate aminotransferase were also increased by the $\mathrm{AlCl}_{3}$ treatment; the first two but not aspartate aminotransferase were restored by vitamin E separately or together with vitamin $\mathrm{C}$.

We conclude that vitamin $\mathrm{E}$ separately or together with vitamin $\mathrm{C}$ suppressed cytogenetic injury and damage to some biochemical pathways of rat organs induced by $\mathrm{AlCl}_{3}$.
\end{abstract}

Keywords: albino rats, aluminum chloride, blood indices, rat organs, vitamin E, vitamin C.

\section{Introduction}

Aluminum is a well-known toxic agent and represents a severe problem in a variety of medical (Nicolini et al. 1992) and environmental situations (Meranger 1989). The evidence implicating aluminium as a neurotoxin has been continuously mounting. Research on both animals and humans has linked it with neurocognitive dysfunction and in some cases death (Rifat et al. 1990). The major sources of aluminum include air, food and water (Michel 1990), and the gastrointestinal tract constitutes the main route of entry into the body. However, the absorption rate is low in normal human subjects (Brown et al. 1986).

Aluminum hydroxide, administered therapeutically in large quantities as an antacid and phosphate binder has been suggested to contribute to aluminum accumulation and toxicity (Lione 1985). Chronic exposition can cause alterations in skeletal, nervous, hematopoietic and respiratory systems (Chen et al. 2002; Cambell 2002). Blood urea is the principal end product of protein catabolism and a good indicator of kidney function. Uric acid is the end product of catabolism of purine bases; increased concentrations in the blood over the normal range might be due to extra degradation of purines in the liver, or an inability to excrete uric acid by the kidneys (Varely 1987). Creatinine appears in the serum in amounts proportional to the body's muscle mass and is more readily excreted by the kidneys than urea or uric acid (Pevicharova et al. 1997).

Blood enzymes are normally found in small amounts in circulation because of normal tissue turnover. Alanine aminotransferase as a liver enzyme significantly elevates in hepatobiliary disease, but also in connection with damage to the heart or skeletal muscle as well as liver parenchyma. Alkaline phosphatase is present on the cell surfaces in most human

* Author for correspondence: tel +970 (8)28 60700/ +970 (59)98 64932 email : bzabut@iugaza.edu.ps 
tissues, and belongs to a group of enzymes that catalyze the hydrolysis of phosphomonoesters at alkaline $\mathrm{pH}$. High activity is found in the intestine, liver, bone, spleen and kidneys (Stryer 1995). Aluminum ions alter the properties and structure of cellular membranes, inhibiting many enzymes (Platt et al. 2001; Abreo \& Glass 1993), and can act as antagonists for other elements such as calcium, magnesium, iron, silicon, phosphorus, copper and zinc (Ward et al. 2001).

Vitamin $\mathrm{C}$ is essential for the formation of collagen and intracellular material, bone, teeth and for the healing of wounds. It helps maintain elasticity of the skin aids the absorption of iron and improves resistance to infection. Vitamin E is the primary liposoluble antioxidant, perhaps important in scavenging free oxygen radicals and in stabilizing cell membranes, maintaining permeability (Packer 1993). Antioxidants such as vitamins E and C, coenzyme Q, glutathione and selenium ions can act synergistically, preventing lipid peroxidation and cell destruction (Escott-Stump \& Mahan 2000).

The Gaza strip was exposed to Israeli bombing from Dec 272008 to Jan 18 2009, resulting in high concentrations of heavy metals. Such environmental contaminants can be transmitted to humans, causing many health complications (Manduca et al. 2009). Although many studies have been carried out on the toxic effect of aluminium ions and the antioxidant effects of vitamin E and C (Hayes et al. 2001; Eastmond et al. 2001; Manduca et al. 2009; AlFaisal 2010), their effects on the body at a molecular level are still controversial. The present study investigates the different effects of $\mathrm{AlCl}_{3}$ on blood indices of albino rats, and the subsequent response of rat tissues to therapeutic actions of vitamins $\mathrm{E}$ and $\mathrm{C}$.

\section{Materials \& Methods}

The study design involved one control and three treatment groups. It used 24 adult male albino rats, each weighing 100-120 gm, purchased from the breeding unit of the Biology Department, IUG. They were kept in plastic cages with wire mesh covers for one week before experimentation, and then divided in groups of six into one control and three treatment groups. Group one was administered $40 \mathrm{mg} / \mathrm{AlCl}_{3}$ dissolved in the drinking water (Fyiad 2007); group two was given $40 \mathrm{mg} / \mathrm{l} \mathrm{AlCl}_{3}$ plus vitamin $\mathrm{E}(150 \mathrm{mg} / \mathrm{kg}$ ) (El-Nahas 1993); and group three had $40 \mathrm{mg} / 1 \mathrm{AlCl}_{3}$ plus vitamins $\mathrm{E}$ and $\mathrm{C}(150 \mathrm{mg} / \mathrm{kg}$ ) (El-Nahas 1993). Commercial balanced diet and water were continuously and regularly supplied ad libitum to the animals throughout the experimental period. The duration of the experiment was 8 weeks, when blood samples were collected from the jugular vein for hematological and biochemical examination.

Routine hematological parameters and a complete blood count was carried out using an automated 18-parameter hematology analyzer (ABX Micros 60, Horiba ABX, France). Clear serum samples were separated by centrifugation at $3000 \mathrm{rpm}$. for $20 \mathrm{~min}$, collected and stored in a deep freeze at $\left(-20^{0} \mathrm{C}\right)$ for biochemical analysis. Glucose, triglyceride and cholesterol were determined using classical methods described by Trinder (1979), Fossati \& Prencipe (1982) and Allain et al. (1974), respectively. Serum urea measurement was based on cleavage of urea with urease (Fawcett \& Scott 1960). Serum uric acid was determined according to Fossatti et al. (1980). Serum creatinine was measured without protein precipitation according to Bartels et al. (1972). Activities of serum aspartate aminotransferase and alanine aminotransferase were determined according to the classic method of Reitman \& Frankel (1957); measurement of serum alkaline phosphatase activity was also based on the method of Bessey et al. (1946).

Data were analyzed using SPSS version 13 for Windows. ANOVA was used to test for differences among groups; differences were considered significant if $\mathrm{p}<0.05$. 


\section{Results}

Table 1 summarizes the effect of $\mathrm{AlCl}_{3}$ and vitamins $\mathrm{C}$ and $\mathrm{E}$ on hematological parameters. After eight week of $\mathrm{AlCl}_{3}$ administration, there was significant decrease in the total red blood cells, red blood cells, hemoglobin and hematocrit compared to the control. In contrast, white blood cells, lymphocytes, corpuscular volume, corpuscular hemoglobin and platelets showed a significant increase compared to the control. There was a non-significant increase in corpuscular hemoglobin concentration. Administration of vitamin $\mathrm{E}$ alone, or with vitamin $\mathrm{C}$, failed to counteract the effect of $\mathrm{AlCl}_{3}$ on red blood cells, hematocrit, corpuscular volume, corpuscular hemoglobin, corpuscular hemoglobin concentration and platelets. Vitamin E alone counteracted the effect of the ion on white blood cells, lymphocytes and hemoglobin.

\begin{tabular}{|c|c|c|c|c|}
\hline Parameter & control & $\mathrm{AlCl}_{3}$ & $\begin{array}{c}\mathrm{AlCl}_{3} \\
+\operatorname{vitamin} \mathrm{E}\end{array}$ & $\begin{array}{c}\mathrm{AlCl}_{3} \\
+ \text { vitamins } \\
\mathbf{E} \& \mathrm{C}\end{array}$ \\
\hline White blood cells $\left(\times 10^{3}\right.$ cell $\left./ \mu \mathrm{l}\right)$ & $3.90^{\mathrm{b}} \pm 0.19$ & $6.5^{\mathrm{a}} \pm 0.24$ & $4.10^{\mathrm{b}} \pm 0.36$ & $5.85^{\mathrm{a}} \pm 0.29$ \\
\hline Lymphocytes & $60.6^{\mathrm{b}} \pm 2.5$ & $78.2^{\mathrm{a}} \pm 3.0$ & $62.6^{\mathrm{b}} \pm 3.2$ & $75.9^{\mathrm{a}} \pm 2.3$ \\
\hline Red blood cells $\left(\times 10^{6}\right.$ cell $\left./ \mu \mathrm{l}\right)$ & $11.19^{\mathrm{a}} \pm 0.20$ & $9.14^{\mathrm{b}} \pm 0.35$ & $9.25^{\mathrm{b}} \pm 0.30$ & $9.51^{\mathrm{b}} \pm 0.31$ \\
\hline Hemoglobin $(\mathrm{g} / \mathrm{dl})$ & $16.26^{\mathrm{a}} \pm 0.70$ & $15.18^{\mathrm{b}} \pm 0.18$ & $16.18^{\mathrm{a}} \pm 0.19$ & $15.45^{\mathrm{b}} \pm 0.20$ \\
\hline Hematocrit (\%) & $65.9^{\mathrm{a}} \pm 1.1$ & $53.0^{\mathrm{b}} \pm 1.2$ & $52.5^{\mathrm{b}} \pm 1.3$ & $51.6^{\mathrm{b}} \pm 1.3$ \\
\hline Corpuscular volume (fi) & $14.5^{\mathrm{c}} \pm 0.2$ & $16.6^{\mathrm{b}} \pm 0.2$ & $17.4^{\mathrm{b}} \pm 0.3$ & $16.2^{\mathrm{b}} \pm 0.2$ \\
\hline Corpuscular hemoglobin (pg) & $27.14^{\mathrm{b}} \pm 0.20$ & $28.65^{\mathrm{a}} \pm 0.16$ & $30.84^{\mathrm{a}} \pm 0.19$ & $29.97^{\mathrm{a}} \pm 0.23$ \\
\hline Corpuscular hemoglobin concentration $(\mathrm{g} / \mathrm{dl})$ & $53.52^{\mathrm{b}} \pm 0.25$ & $57.95^{\mathrm{a}} \pm 0.31$ & $56.70^{\mathrm{a}} \pm 0.36$ & $54.20^{\mathrm{a}} \pm 0.42$ \\
\hline Platelets $\left(\times 10^{3} / \mu \mathrm{l}\right)$ & $595.1^{\mathrm{c}} \pm 23.3$ & $790.0^{\mathrm{a}} \pm 25.2$ & $731.8^{\mathrm{b}} \pm 31.3$ & $723.0^{\mathrm{b}} \pm 33.9$ \\
\hline
\end{tabular}

Table 1: Hematological indices of the rats administrated $\mathrm{AlCl}_{3}$, vitamin $\mathrm{E}$ and vitamin $\mathrm{C}$ (all values expressed as mean $\pm \mathrm{SE}$ ). Means with different subscripts in the same row differ significantly $(\mathrm{p}<0.05)$.

Table 2 shows changes in glucose, triglycerides and cholesterol concentrations in the experimental groups. Aluminium treatment significantly decreased serum glucose levels (by $30 \%)$ and increased significantly triglycerides (28\%) and cholesterol (20\%). Treatments with vitamin $\mathrm{E}$ alone or with vitamin $\mathrm{C}$ did not restore these compounds to control levels.

\begin{tabular}{|c|c|c|c|c|}
\hline Parameter & control & $\overline{\mathrm{AlCl}_{3}}$ & $\begin{array}{c}\mathrm{AlCl}_{3} \\
+ \text { vitamin } \mathrm{E}\end{array}$ & $\begin{array}{c}\mathrm{AlCl}_{3} \\
+ \text { vitamins } \\
\mathrm{E} \& \mathrm{C}\end{array}$ \\
\hline Glucose (mg/dl) & $95.2^{\mathrm{a}} \pm 3.1$ & $66.8^{\mathrm{b}} \pm 2.2$ & $68.8^{b} \pm 2.2$ & $67.5^{\mathrm{b}} \pm 2.3$ \\
\hline Triglycerides $(\mathrm{mg} / \mathrm{dl})$ & $88.5^{b} \pm 2.5$ & $113.3^{\mathrm{a}} \pm 2.3$ & $105.7^{\mathrm{a}} \pm 3.4$ & $103.7^{\mathrm{a}} \pm 2.2$ \\
\hline Cholesterol (mg/dl) & $129.1^{\mathrm{c}} \pm 2.3$ & $155.0^{\mathrm{a}} \pm 3.2$ & $152.2^{\mathrm{a}} \pm 3.3$ & $143.6^{\mathrm{b}} \pm 2.2$ \\
\hline Urea (mg/dl) & $25.3^{\mathrm{b}} \pm 0.1$ & $28.3^{\mathrm{a}} \pm 1.1$ & $26.5^{\mathrm{b}} \pm 1.2$ & $25.4^{\mathrm{b}} \pm 2.1$ \\
\hline Uric acid (mg/dl) & $3.51^{\mathrm{b}} \pm 0.20$ & $6.21^{\mathrm{a}} \pm 0.26$ & $3.77^{\mathrm{b}} \pm 0.24$ & $4.11^{\mathrm{b}} \pm 0.25$ \\
\hline Creatinine $(\mathrm{mg} / \mathrm{dl})$ & $0.60^{\mathrm{b}} \pm 0.01$ & $0.75^{\mathrm{a}} \pm 0.02$ & $0.65^{\mathrm{b}} \pm 0.01$ & $0.62^{\mathrm{b}} \pm 0.02$ \\
\hline Alanine aminotransferase $(\mathrm{IU} / \mathrm{ml})$ & $25.5^{\mathrm{b}} \pm 0.3$ & $30.8^{\mathrm{a}} \pm 0.4$ & $28.1^{\mathrm{b}} \pm 0.3$ & $27.4^{\mathrm{b}} \pm 0.3$ \\
\hline Aspartate amino transferase (IU/ml) & $21.9^{c} \pm 0.4$ & $31.4^{\mathrm{a}} \pm 0.4$ & $28.7^{b} \pm 0.5$ & $29.7^{\mathrm{b}} \pm 0.6$ \\
\hline alkaline phosphatase (IU/ml) & $81.5^{\mathrm{b}} \pm 0.6$ & $100.1^{\mathrm{a}} \pm 4.3$ & $90.1^{\mathrm{b}} \pm 2.2$ & $88.2^{\mathrm{b}} \pm 2.2$ \\
\hline
\end{tabular}

Table 2: Chemical concentrations in albino rats administrated $\mathrm{AlCl}_{3}$, vitamin $\mathrm{E}$ and vitamin $\mathrm{C}$ (all values expressed as mean $\pm \mathrm{SE}$ ). Means with different subscripts in the same row differ significantly $(\mathrm{p}<0.05)$.

Levels of non-protein nitrogenous constituents for treatment groups are also given in Table 2. The aluminium treatment significantly increased urea (by 12\%), uric acid (77\%) and creatinine 
levels $(25 \%)$ compared to the control. Vitamin E separately or together with vitamin C significantly counteracted the effects of aluminium.

Activities of serum aspartate amino transferase, alanine aminotransferase and alkaline phosphatase (Table 2) increased significantly following aluminium treatment. As for the nitrogenous compounds, these increases were counteracted by treatment with vitamin $\mathrm{E}$ alone or together with vitamin C. In contrast, aspartate amino transferase activity was not counteracted at all.

\section{Discussion}

This study aimed to determine the toxic effects of the aluminium ion, and the therapeutic effects of vitamin $\mathrm{E}$ and vitamin $\mathrm{C}$, on rats. We found highly significant decreases in hemoglobin, red blood cells and hematocrit among aluminium-treated rats, as have others (Karmaker et al. 2000). The reduction in hemoglobin content might be due to increased rate of destruction or reduction in the rate of formation of red blood cells. This intepretation was supported by the low levels of red blood cells in the treated groups. Reductions in hematocrit, red blood cells and hemoglobin might be attributed to hyperactivity of bone marrow, leading to production of red blood cells with impaired integrity that are easily destroyed in the circulation (Karmaker et al. 2000). On the other hand, these decreases could alternatively reflect a lower oxygen supply to different tissues, resulting in low energy production in the rats. The decrease in hemoglobin could be not only due to decrease in red blood cells count but also to impaired biosynthesis of heme in the bone marrow.

The significant increase in white blood cell levels of aluminium-treated rats might indicate activation of the immune system, a normal cell-mediated immune response (ElDemerdash 2004). The increase in lymphocytes could be due to the toxic action of the aluminium ion that stimulates the hemopoietic system to release more of these cells, causing an increase in their number in the blood stream.

The increase in corpuscular volume, corpuscular hemoglobin, corpuscular hemoglobin concentration and platelets were consistent with changes in red blood cell counts and hemoglobin levels. These changes may be correlated with some pathological changes developed in blood-forming organs, or with the destruction of red blood cells, or with both factors. In this regard, from similar results Naylor (1971) concluded that anemia resulted from hemodilation, extra vascular hemolysis and toxic dyshemopiosis.

Our findings show that vitamin $\mathrm{E}$ on its own counteracted the effects of the aluminium ion on white blood cells, lymphocytes and hemoglobin. Vitamin E and vitamin C separately increase the activities of antioxidant enzymes in various tissues of rats, especially liver tissues and also vitamin E on bone marrow, where the different blood cells are formed (Shireen et al. 2008).

Our findings also revealed a decrease in serum glucose levels in response to aluminium. Indirectly, aluminium is known to play a specific role in carbohydrate metabolism (Thirunavukkarasu \& Sakthisekaran 2003). Concerning lipid metabolism, our results demonstrated that triglycerides and total cholesterol levels increased in response to aluminium, consistent with increasing lipogenesis in the liver (Thirunavukkarasu \& Sakthisekaran, 2003). Vitamin E separately or together with vitamin C could not counteract the effects of the aluminium ion on glucose, cholesterol and triglycerides. This indicates that vitamin $\mathrm{E}$ is only indirectly involved in metabolism of these compounds via defending the integrity of cells against oxidating agents. Vitamin E mediates mitochondrial superoxide generation, suggesting a possible mode of action at tissue level, and it also modulates the expression and/or activation of redox-sensitive biological response modifiers that regulate important cellular events (Chow 2004). 
Enhanced protein catabolism and accelerated amino acid deamination in response to low glucose levels caused by aluminium ion administration is the best interpretation for the elevated levels of urea. The presence of toxic compounds can increase blood urea and decrease plasma protein (Berne \& Levy 1998). The observed increase in uric acid concentration might be due to extra degradation of purines in the liver, or an inability to excrete uric acid by the kidneys (Varely 1987). An increase in creatinine has been seen, interpreted as caused by a decrease in muscle mass (Pevicharova et al. 1997) or abnormal glomerular function of the kidneys induced by $\mathrm{AlCl}_{3}$ administration (Berne \& Levy 1998). The observation that vitamin $\mathrm{E}$ separately or together with vitamin $\mathrm{C}$ counteracted the toxic effects of the aluminium ion in forming these nitrogenous compounds indicates that the vitamins reverse and thus inhibit interactions with metabolic enzymes involved in their synthesis in the liver and muscles.

Serum transaminases (aspartate amino transferase and alanine aminotransferase) and alkaline phosphatase exhibited a significant increase in treated rats, perhaps indicating persistent cellular injury (Bansal et al. 2005). Elevated activities of serum transaminases could be a sign of impaired liver function. Alkaline phosphatase has a specific location within both sinusoidal and bile canalicular membranes, accounting for its more predominant elevation in certain disorders (Bansal et al. 2005): acute cell necrosis liberates alkaline phosphatase into the blood circulation and its level is elevated. As with biosynthetic enzymes of nitrogen compounds, vitamin $\mathrm{E}$ separately or together with vitamin $\mathrm{C}$ reversed the toxic effects of aluminium ions on the activities of alkaline phosphatase and alanine aminotransferase, but not aspartate amino transferase. Their effect on aspartate amino transferase requires further investigation.

We conclude that aluminum ions significantly decrease red blood cell counts, hemoglobin, hematocrit and glucose, and significantly increase white blood cell counts, lymphocytes, corpuscular volume, corpuscular hemoglobin, corpuscular hemoglobin concentration, platelets, triglycerides, cholesterol, urea, uric acid, creatinine and the activity levels of alanine aminotransferase, aspartate amino transferase and alkaline phosphatase. Vitamin $\mathrm{E}$ on its own counteracts the effect of $\mathrm{AlCl}_{3}$ on white blood cell counts, hemoglobin and lymphocytes. Vitamin $\mathrm{E}$ alone or together with vitamin $\mathrm{C}$ counteracts the effects of aluminium ions on urea, uric acid, creatinine and on the activities of alanine aminotransferase and alkaline phosphatase. Consequently, vitamin E separately or together with vitamin $\mathrm{C}$ suppresses cytogenetic injuries and damage to some biochemical organ pathways (e.g. liver, kidney, bone marrow) induced by $\mathrm{AlCl}_{3}$ administration .

\section{Acknowledgements}

The authors thank Miss Walaa S Neamah and Miss Nedaa A Shnewra, B.Sc. (Biology Dept., Faculty of Science, IUG, Gaza) for their help in the experimental part of the study.

\section{References}

Abreo K \& Glass J (1993) Cellular, biochemical and molecular mechanisms of aluminium toxicity. Nephrology Dialysis Transplantation 8(1): 5

Al-Faisal AHM, Hussein AM \& Abdul Kaleg AR (2010) Estimation of DNA damage, cytotoxicity and antioxidant status of heavy metals and benzene among petrol workers in Baghdad-Irag. Isan Journal of Pharmaceutical Sciences 6(1): 85-94

Allain CC, Poon LS \& Chan CSG (1974) Enzymatic determination of total serum cholesterol. Clinical Chemistry 20 (4): 470-75

Bansal AK, Bansal M \& Soni G (2005) Protective role of Vitamin E pre-treatment on N-nitrosodiethylamine induced oxidative stress in rat liver. Chemico-Biological Interactions 156: 101-111

Bartels H, Bohmer M \& Heierli C (1972) Serum creatinine determination without protein precipitation. Clinica Chemica Acta 37: 193-197

Berne MR \& Levy NM (1998) Physiology. 4th ed. Mosby, New York. pp 910-929

Bessey OA, Lowry DH \& Brock JM (1946) Method for the determination of alkaline phosphatase with five cubic milliliters of serum. Journal of Biological Chemistry 146: 321 
Brown S, Mendoza N \& Bertholt RK (1986) Absorption of aluminum from aceglutamide in healthy adult males. Research Communications in Chemical Pathology \& Pharmacology 53:105-116

Cambell A (2002) The potential role of aluminum in Alzheimer's disease. Nephrology Dialysis Transplantation 17: 2-17

Chen J, Wang M \& Run D (2002) Early chronic Al exposure impairs long-term potentiality and depression to the rat dentate gurus in vivo. Neuroscience 112 (4): 879

Chow CK (2004) Biological functions and metabolic fate of vitamin E. Journal of Biomedical Science 11: 295302

Eastmond DA, Schuler M \& Franz CH (2001) Characterization and mechanisms of chromosomal aberrations induced by benzene in mice and humans. Research Reports of the Health Effects Institute 103: 69-80

El-Demerdash FM (2004) Antioxidant effect of vitamin E and selenium on lipid peroxidation, enzyme activities and biochemical parameters in rats exposed to aluminium. J. Trace Elements in Medical Biology 18: 113122

El-Nahas SM, Mattar FE \& Mohamed AA (1993) Protective effects of vitamin C and E. Mutation Research 301:143

Escott-Stump S \& Mahan LK (2000) Krause's Food, Nutrition, and Diet Therapy. 10th ed. WB Saunders, Philadelphia, PA

Fawcett JK \& Scott JE (1960) A rapid and precise method for the determination of urea. Journal of Clinical Pathology 13:156-159

Fossati P \& Prencipe L (1982) Serum triglycerides determined colorimetrically with an enzyme that produces hydrogen peroxide. Clinical Chemistry 28 (10): 2077-80

Fossatti P, Prencipe L \& Berti G (1980) Use of 3,5-dichloro-2-hydroxy-benzenesulfonic acid/4-aminophenazone chromogenic system in direct enzymic assay of uric acid in serum and urine. Clinical Chemistry 26: 227-31

Fyiad AA (2007) Aluminum toxicity and oxidative damage reduced ion by melatonin in rats. Journal of Applied Scientific Research 3(10): 1210-1217

Hayes RB, Songnian Y, Dosemeci M \& Linet M (2001) Benzene and lymphohematopoietic malignancies in humans. American Journal of Industrial Medicine 40(2): 117-26

Karmakar R, Bhattacharya R \& Chatterjee M (2000) Biochemical, haematological and histopathological study in relation to time-related cadmium-induced hepatotoxicity in mice. Biometals 13(3): 231-239

Lione A (1985) Aluminum toxicology and the aluminium-containing medications. Pharmacology \&Therapeutics 29: 255-285

Manduca P, Barbieri M \& Barbieri M (2010) Analysis of pilot survey of metal content in samples of hair collected in December 2009 in Gaza. http://www.newweapons.org.,.

Meranger JC (1989) How aluminium levels in subsurface drinking water supplies in Canada can be used to predict possible impact by acidic deposition. pp. 107-116 in Lewis, T.E.(ed) Environmental Chemistry and Toxicology of Aluminium. Lewis Publications, Chelsea, Ml.

Michel P, Commenges D \& Dartigues JF (1990) Study of the relationship between Alzheimer's disease and aluminum in drinking water. Neurobiology of Aging 11:264

Naylor S (1971) The hematology and histopathology of Trypanosoma congolense infection in cattle. Tropical Animal Health \& Production 3: 159-168

Nicolini M, Zatta PF \& Corain B (1992) Aluminum in Chemistry, Biology and Medicine. Cortina lntern, Verona and Raven Press, New York.

Packer L (1993) Vitamin E: biological activity and health benefits: Overview. p. 977-982 in Packer L \& Fuchs J (eds.) Vitamin E in health and disease. New York, Marcel Dekker, Inc.

Pevicharova GT, Dimova PI \& Atanasova-Goranova VK (1997) Effect of food products on endogenous generation of nitrosamines in rats. British Journal of Nutrition 78(2) :325-45

Platt B, Fiddler G, Riedel G \& Henderson Z (2001) Al toxicity in the rat brain: histochemical and immunocytochemical evidence. Brain Research Bulletin 55 (2), 257

Reitman S \& Frankel S (1957) A colorimetric method for the glutamic-pyruvate transaminase. American Journal of Clinical Pathology 28: 56-63

Rifat SL, Eastwood MR \& Crapper McLachlan DR (1990) Effects of exposure of miners to aluminum powder. Lancet 336:1162-1165

Shireen KF, Pace RD \& Mahboob M (2008) Effects of dietary vitamin E, C and soybean oil supplementation on antioxidant enzyme activities in liver and muscles of rats. Food \& Chemical Toxicology 46: 3290-4

Stryer L (1995) Biochemistry. 4th ed. W.H. Freeman and Company, New York, USA. pp. 607-610

Thirunavukkarasu C \& Sakthisekaran D (2003) Influence of sodium selenite on glycoprotein contents in normal and N-nitrosodiethylamine initiated and phenobarbital promoted rat liver tumors. Pharmacological Research 48:167-173

Trinder P (1969) Glucose GOD-PAP method Enzymatic colorimetric method. Annals of Clinical Biochemistry 6: 24-27 
Varely H (1987) Practical clinical biochemistry. 6th ed. Gowenlock AH, McMurray JR \& McLauchlan DM (eds). London, Heinemann Medical Books. pp 477-549

Ward RJ, Zhang Y \& Crichton RR (2001) Aluminium toxicity and iron homeostasis. Journal of Inorganic Biochemistry 87(1-2): 9

الملخص العربي

\section{تحديد المؤشرات الخاصة بدم القئران البيضاء المعالجة بكلوريا

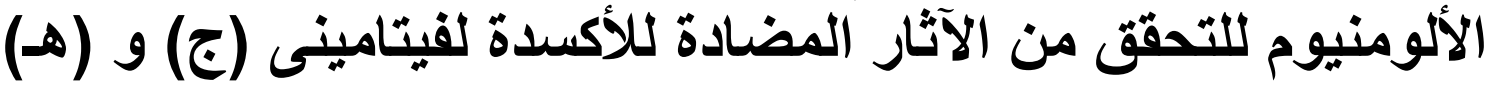 إسماعيل عبد العزيز ${ }^{1}$ بكر الزعبوط2}

1 قسم الأحياء،كلية العلوم، الجامعة الإسلامية، غزة، فلسطين.

2 رئيس قسمي الكيمياء و الكيمياء الحيوية, كلية العلوم, الجامعة الإسلامية، غلية, غزة, فلسطين.

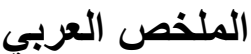

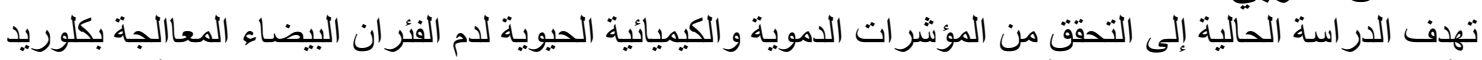

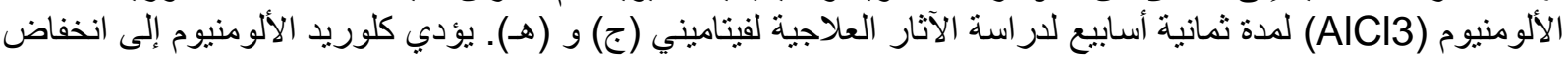

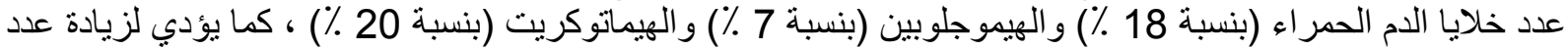

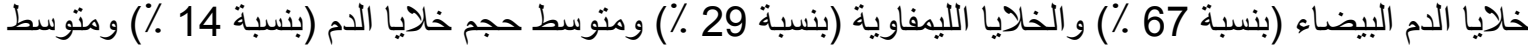

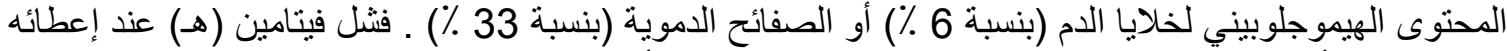

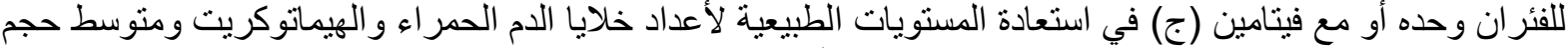

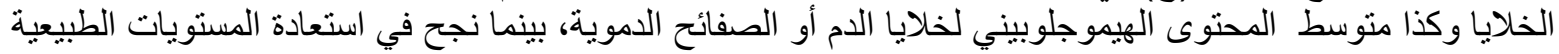

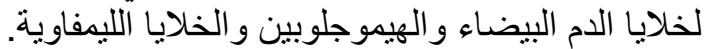

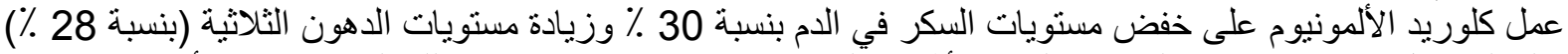

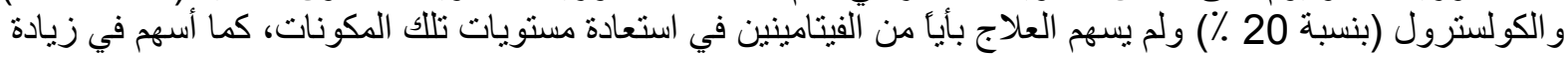

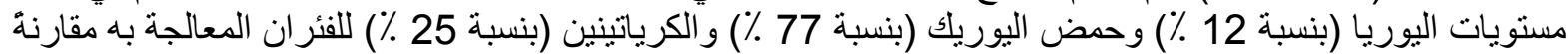

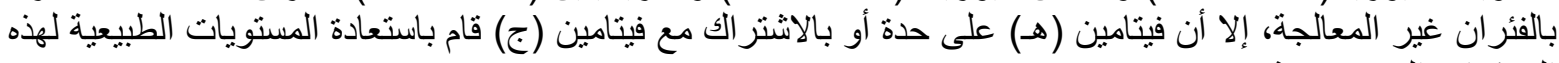
المركبات النيتروجينية.

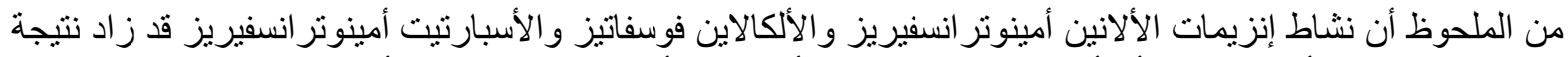

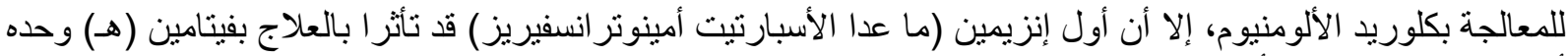

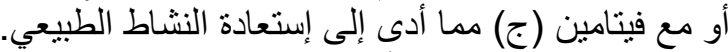

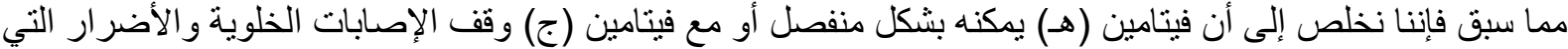
تلحق ببعض المسار ات الحيوية لأعضاء الفئران و التي تتسبب فئهل فيها مادة كلوريد الألمونيو م. 